\title{
Analisis Kesesuaian Lahan Lanskap Candi Sumberawan Sebagai Objek Wisata Sejarah di Singosari Kabupaten Malang
}

\author{
Hioronimus Soka ${ }^{1}$, Debora Budiyono ${ }^{1 *}$, Riyanto Djoko ${ }^{1}$ \\ 1. Prodi Arsitektur Lanskap, Fakultas Pertanian, Universitas Tribhuwana Tunggadewi Malang, \\ Jl. Telaga Warna, Tlogomas, Malang 65144, Indonesia \\ *E-mail: debora.budiyono@unitri.ac.id
}

\begin{abstract}
Land suitability analysis of the Sumberawan Temple landscape as a historical tourist attraction in Singosari, Malang Regency. Sumberawan Temple is located in Toyomarto Village, Singosari District, Malang Regency. The Sumberawan Temple area has a natural landscape, unique landscape beauty, historical buddhist temple buildings and preserved flora and fauna so that it has the potential to be developed into historical tourism objects. However, the absence of land suitability analysis for tourism in Sumberawan Temple, could possibly threaten and lose its historical value. This study aimed to analyze the land suitability of the Suberawan Temple landscape as a historical tourist attraction in Singosari, Malang Regency. Data collection techniques used in this study were quantitative descriptive methods. While the method of analysis was the method of land suitability analysis consisting of topography analysis, soil characteristics, hydrology, and land cover. The results showed that the development of a suitable area of Candi Sumberawan was 12,96 $\mathrm{Ha}(82 \%)$ and a very suitable area was $2,84 \mathrm{Ha}(18 \%)$ of the total area of $15,80 \mathrm{Ha}(100 \%)$.
\end{abstract}

Key words: historical landscape, land suitability analysis, Sumberawan Temple

\section{Pendahuluan}

Tanah Jawa memiliki banyak peninggalan situs bersejarah salah satunya candi. Candi atau candhika merupakan pendharmaan untuk memuliakan bagi raja yang telah meninggal pada zaman Hindu. Menurut Maryanto (2007) bahwa pada saat ini umumnya candi banyak digunakan masyarakat sebagai tempat ritual, istana, pemandian atau petirtaan, objek wisata, gapura, dan lainnya. Kabupaten Malang memiliki banyak peninggalan candi baik Hindu dan salah satunya Candi Sumberawan yang dibangun pada masa kerajaan Majapahit yang berada di Kabupaten Malang dan masih digunakan oleh umat Budha sampai saat ini terutama pada saat perayaan hari raya Waisak (Lopes, 2016).

Kawasan Candi Sumberawan memiliki konsep "patirtan" dan "penguripan", dimana sebagai patirtan air digunakan untuk upacara ritual keagamaan (Waisak dan Kejawen), pusat upacara bersih desa, dan slametan banyu masyarakat Desa Toyomerto. Sedangkan penguripan digunakan untuk kepentingan keagamaan tetapi juga menjadi sumber bagi kebutuhan air masyarakat (Titisari dkk., 2017). Menurut Sitawati dkk., (2015) bahwa kawasan Candi Sumberawan memiliki kearifan lokal, dimana tata nilai atau perilaku hidup keseharian masyarakat lokal Sumberawan berinteraksi dengan lingkungan sekitar secara arif yang membentuk karakter sehingga terwujud sebuah komunitas yang dapat diwariskan.

Candi Sumberawan pada awalnya hanya bersifat arkeologis namun saat ini pengembangan dan pembangunan kawasan mengarah pada tempat tujuan wisata rekreatif tanpa memperhatikan keberlanjutan kawasan lanskap alami dan memiliki nilai sejarah tinggi (Piduwatu, 2015). Menurut Buwono dkk., (2017) bahwa pengelolaan mata air Kawasan Candi Sumberawan telah dilakukan berdasarkan komponen konservasi yaitu pemanfaatan, perlindungan, dan pelestarian namun dimanfaatkan tanpa adanya rencana penataan yang baik serta pemanfaatan sumberdaya pada kawasan tanpa pengelolaan yang berkelanjutan, hal ini dapat menurunkan kualitas lingkungan dan nilai dari lanskap sejarah tersebut menurun.

Tindakan pelestarian situs Sumberawan harus dilakukan yaitu stupa dan artefak-artefak peninggalannya, lingkungan alamnya, sumber mata air, budaya dengan simbol-simbol yang berbentuk ritual, kepercayaan, dan larangan di telaga mata air (Ramli dan Wikantiyoso, 2018). Berdasarkan kondisi tersebut analisis kesesuaian lahan sangat diperlukan untuk pengembangan lanskap kawasan Candi Sumberawan berdasarkan topografi, karakteristik tanah, hidrologi, dan tutupan lahan. Dengan melakukan analisis spasial kesesuaian lahan dapat menjadi pedoman pengembangan dan pengelolaan objek wisata sejarah secara 
berkelanjutan. Tujuan penelitian ini adalah menganalisis Kesesuaian Lahan Lanskap Candi Sumberawan sebagai objek wisata sejarah di Singosari Kabupaten Malang.

\section{Metode}

\subsection{Lokasi dan Waktu Penelitian}

Penelitian dilakukan di kawasan Candi Sumberawan dengan luas kawasan 18,50 Ha dan berdasarkan batas ekologi kawasan candi (Gambar 1). Waktu penelitian berlangsung enam bulan dimulai dari bulan Maret 2019 sampai Agustus 2019. Alat yang digunakan adalah kamera digital, komputer, GPS, dan ArcGIS. Sedangkan bahan yang digunakan adalah peta kawasan candi.

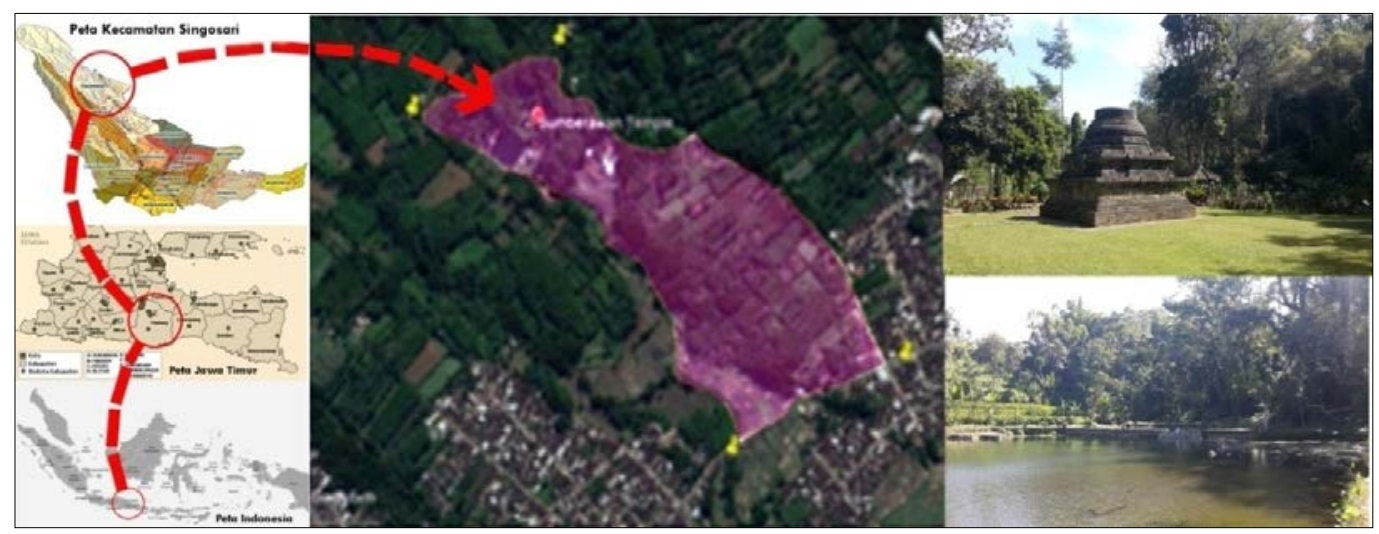

Gambar 1. Lokasi Penelitian (Google Earth, 2019 dan Survei, 2019)

\subsection{Metode Penelitian}

Penelitian ini menggunakan metode survei dengan pendekatan deskriptif kuantitatif. Sedangkan metode analisis menggunakan analisis kesesuaian lahan yaitu topografi, karakteristik tanah, hidrologi, dan tutupan lahan. Pelaksanaan penelitian ini dilaksanakan tiga tahap yaitu investarisasi data, analisis data, dan analisis penilaian kesesuaian lahan lanskap Candi Sumberawan sebagai objek wisata sejarah. Metode pengumpulan data yang digunakan meliputi data primer dan data sekunder yaitu aspek sejarah, biofisik, dan sosial. Pengumpulan data primer diperoleh melalui survei yaitu wawancara, pengamatan, dan pengukuran di lokasi penelitian. Sedangkan data sekunder diperoleh dari jurnal, buku, dan dokemen-dokumen yang berkaitan dengan penelitian.

\subsection{Analisis Kesesuaian Lahan Kawasan Candi Sumberawan}

Menurut Hardjowigono dan Widiatmaka (2007) bahwa penilaian kesesuaian lahan sebagai objek wisata dari aspek fisik terdiri dari topografi, karakteristik tanah, hidrologi, dan tutupan lahan (Tabel 1). Oleh karena itu penilaian aspek fisik atau bentang lahan untuk pengembangan kawasan wisata pada lanskap Candi Sumberawan berdasarkan kriteria topografi, karakteristik tanah, hidrologi, dan tutupan lahan dengan nilai bobot yang sama. Penilaian aspek fisik melalui analisis spasial pada aspek fisik masing-masing kriteria menghasilkan peta kemudian di overlay menggunakan ArcGIS. Menentukan nilai kesesuaian lahan menggunakan evaluasi kesesuaian lahan dengan pendekatan tutupan lahan yaitu hutan campur, hutan pinus, persawahan, pertanian lahan kering semusim, sungai, air bendungan, kawasan situs candi, pemukiman, dan semak. Formula penilaian kesesuaian lahan kawasan Candi Sumberawan (Budiyono, 2013), yaitu:

\begin{tabular}{|c|c|c|c|}
\hline IKL & \multicolumn{3}{|r|}{ 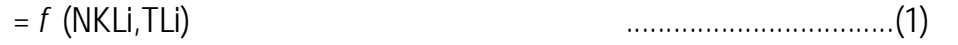 } \\
\hline NKLi & \multicolumn{3}{|l|}{$=(\mathrm{T}+\mathrm{KT}+\mathrm{H})$} \\
\hline TL i & \multicolumn{3}{|c|}{$=(\mathrm{HC}, \mathrm{HP}, \mathrm{PS}, \mathrm{PLKS}, \mathrm{SG}, \mathrm{AB}, \mathrm{KSC}, \mathrm{PK}, \mathrm{SM})$} \\
\hline \multicolumn{4}{|c|}{ Keterangan } \\
\hline IKL & Indeks Kesesuaian Lahan & PS & Persawahan \\
\hline NKL & Nilai Kesesuaian Lahan ke-i & PLKS & Pertanian Lahan Kering Semusim \\
\hline NTLi & Nilai Tutupan Lahan ke-i & SG & Sungai \\
\hline $\mathrm{T}$ & : Topografi & $A B$ & Air Bendungan \\
\hline KT & Karakteristik Tanah & KSC & Kawasan Situs Candi \\
\hline $\mathrm{H}$ & Hidrologi & PK & Pemukiman \\
\hline $\mathrm{HC}$ & Hutan Campur & SM & Semak \\
\hline HP & Hutan Pinus & & \\
\hline
\end{tabular}


Tabel 1. Kriteria Penilaian Kesesuaian Lahan sebagai Objek Wisata

\begin{tabular}{|c|c|c|c|c|}
\hline NNo & Kriteria & Sub kriteria & Skor & Keterangan \\
\hline \multirow[t]{3}{*}{1} & Topografi & Landai & 3 & Permukaan lereng $0-15 \%$ \\
\hline & & Miring & 2 & Permukaan lereng $15-65 \%$ \\
\hline & & Curam & 1 & Permukaan lereng $>65 \%$ \\
\hline \multirow[t]{3}{*}{2} & Karakteristik & Berbatu sedikit & 3 & $0-15 \%$ volume tanah \\
\hline & tanah & Berbatu sedang & 2 & $15-90 \%$ volume tanah \\
\hline & & Berbatu banyak & 1 & $>90 \%$ volume tanah \\
\hline \multirow[t]{3}{*}{3} & Hidrologi & Jernih & 3 & Tidak berwarna \\
\hline & & Keruh & 2 & Berwarna \\
\hline & & Kotor & 1 & Berwarna dan berbau \\
\hline \multirow[t]{3}{*}{4} & Tutupan lahan & Tidak alami & 3 & Penutupan ekosistem < $40 \%$ \\
\hline & & Semi alami & 2 & Penutupan ekosistem 40-80\% \\
\hline & & Alami & 1 & Penutupan ekosistem alami > 80\% \\
\hline
\end{tabular}

Sumber: Hardjowigono dan Widiatmaka (2007)

Penentuan klasifikasi kesesuaian lahan kawasan Candi Sumberawan, yaitu: Klasifikasi tingkat kesesuaian lahan $=\sum \frac{i=1 \text { Skor maksimal }-\sum_{i=1} \text { Skor minimal }}{\sum_{i=1} \text { Kelas klasifikasi }}$

Penilaian indeks kesesuaian kawasan Candi Sumberawan, yaitu: Sangat Sesuai (SS) merupakan lahan yang sangat sesuai untuk dikembangkan sebagai wisata, Cukup Sesuai (CS) merupakan lahan yang cukup sesuai untuk dikembangkan sebagai wisata, Kurang Sesuai (KS) merupakan lahan yang tidak sesuai untuk dikembangkan sebagai wisata.

\section{Hasil dan Pembahasan}

\subsection{Sejarah Kawasan}

Candi Sumberawan terletak di Kecamatan Singosari, Kabupaten Malang dimana candi berada di tengah telaga tepatnya berada di kaki Gunung Arjuno dan saat ini telaga mengalami kekeringan akibat aktivitas manusia sehingga telaga hanya terdapat di bagian selatan candi. Kata Sumberawan berasal dari 'sumber' yang berarti mata air, dan 'rawan' yang berarti 'telaga' sehingga makna Sumberawan berarti sumber kehidupan. Menurut Wurianto 2009, Candi Sumberawan direnovasi oleh pemerintah Belanda pada 1928 dan 1935. Meskipun telaga dan sumber air telah dijadikan sarana hidup masyarakat, namun kondisi stupa candi yang tertutup hutan sehingga ditemukan penduduk dan dilaporkan pada tahun 1904.

Candi Sumberawan berbentuk stupa menyerupai bentuk genta yang merupakan salah satu simbol suci agama Budha. Stupa Sumberawan merupakan monumen lambang agama Budha yang dapat dijadikan indeks sebagai lambang alam dewa atau kahayangan atau Gunung Meru. Stupa Sumberawan sebagai Gunung Mandara dan air telaga disekelilingnya sebagai amerta. Melihat keterkaitan antara air dan candi Budha maka fungsi candi adalah "patirtan". Stupa Candi Sumberawan berbentuk tunggal di atas pondasi persegi dengan alas stupa segi delapan serta material berupa batu andesit. Bentuk Candi Sumberawan berukuran $6,25 \mathrm{~m} \times 6,25 \mathrm{~m}$ dengan tinggi 5,23m namun candi bagian puncaknya mengalami keruntuhan dan para arkeolog tidak dapat merekonstruksi bagian puncak karena keterbatasan dokumen sehingga reruntuhan batu puncak ditumpuk di sebelah utara candi (Titisari, 2017). Saat ini sumber mata air kawasan Candi Sumberawan dimanfaatkan oleh masyarakat untuk irigasi pertanian, air minum, dan wisata sehingga sumber mata air berfungsi "penguripan".

\subsection{Kondisi Biofisik}

Batas wilayah Desa Toyomaro adalah sebelah utara yaitu Desa Randuagung Kecamatan Singosari dan Desa Bedali Kecamatan Lawang. Sebelah timur yaitu Desa Toyomarto dan Kelurahan Candirenggo Kecamatan Singosari. Sedangkan sebelah selatan yaitu Desa Gunungrejo, Kecamatan Singosari, dan Sebelah Barat yaitu hutan atau Perhutani (Gambar 2). Topografi Desa Toyomarto termasuk dataran tinggi dengan ketinggian \pm 622 mdpl. Berdasarkan Badan Meteorologi, Klimatologi, dan Geofisika (2018) suhu rata-rata di Kabupaten Malang berkisar antara $19,1^{\circ} \mathrm{C}$ sampai $26,6^{\circ} \mathrm{C}$. Kelembaban udara raatarata berkisar antara $71^{\circ} \mathrm{C}$ sampai $89^{\circ} \mathrm{C}$ dan curah hujan rata-rata berkisar antara $2 \mathrm{~mm}$ sampai $780 \mathrm{~mm}$. 
Sedangkan curah hujan terendah terjadi pada bulan Juni dan tertinggi pada bulan Desember. Pentingnya mengetahui iklim bagi wisatawan untuk mengetahui kondisi cuaca.

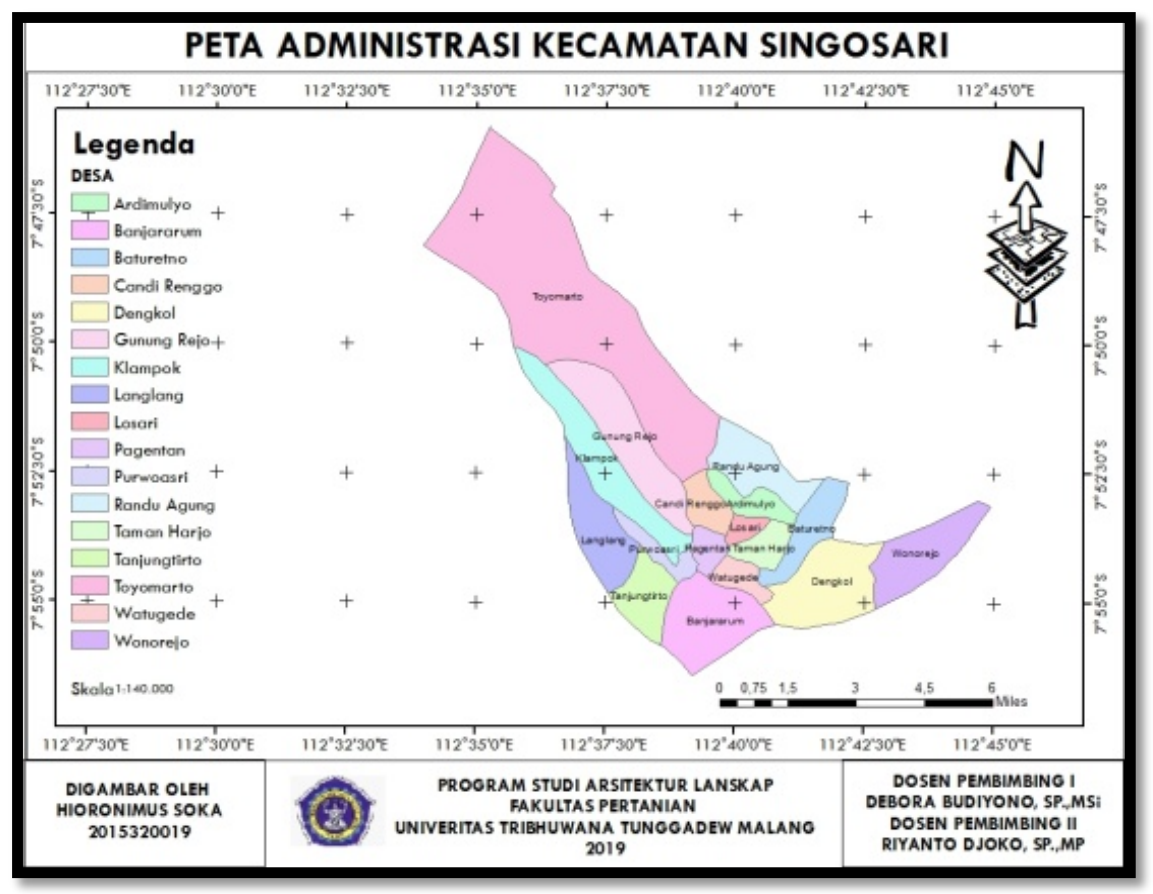

Gambar 2. Peta Administrasi Kecamatan Singosari

Kawasan Candi Sumberawan memiliki ekosistem yaitu hutan, perkebunan, sungai, dan pemukiman. Sedangkan untuk fauna terdapat burung rajawali, burung kutilang, kera, lutung, kumbang, dan projoan. Keberadaan ekosistem tersebut merupakan potensi sumberdaya alam yang memiliki fungsi dan peran yang saling terkait sehingga dibutuhkan upaya menjaga dan melestarikan sumberdaya tersebut. Tanaman kawasan Candi Sumberawan yaitu vegetasi budidaya seperti padi (Oryza sativa L), pisang (Musa paradisiaca L), cabe kecil (Capsicum frutescens), jagung (Zea mays L), dan singkong (Manihot esculenta). Tanaman konservasi yaitu pinus (Pinus merkusii), bambu (Gigantochloa apus), sengon (Albizia chinensis), dan jati (Tectona grandis). Tanaman religi yaitu pandan wangi (Pandanus amaryllfolius), maja (Aegle marmelos), bendo (Artocarpus elastikus), teratai (Nympaea nouchali), puring (Codiaeum variegatum), mawar (Rosa sp), puring (Codiaeum variegatum), andong (Cordyline fruticosa), melati (Jasminum sambac), rumput gajah mini (Axonopus compressus). Sedangkan tanaman hias yaitu pangkas kuning (Duranta repens $L$ ), bayam merah (Aerva sanguinolenta L), iris (Iris sp), bakung putih (Hymenocallis liriosme), palem putri (Adonidia merrillii Becc), sikas (Cycas circinalis L), dan palem kipas (Livistona saribus).

\subsection{Kondisi Sosial Budaya}

Pada umumnya masyarakat Sumberawan sebagai petani, hal ini menunjukkan ketergantungan kehidupan pada alam serta kegiatan dalam musyawarah mufakat yang dilakukan oleh pemerintah desa, lembaga, tokoh masyarakat, dan tokoh agama yang menjadi kebiasaan (Sitawati dkk., 2015). Adat istiadat masyarakat Candi Sumberawan mempunyai pandangan hidup dalam fenomena alami adalah kesakralan alam sebagai bagian dari spiritualitas hidup. Hal ini dipengaruhi oleh alam dan manusia menjadi satu kesatuan yang utuh penuh ketahanan dalam kepercayaan dan pelestarian kearifan lokal dengan memanfaatkan air mertah dalam pengolahan sawah maupun ladang. Konsep "patirtan" dan "penguripan" yang terkandung dalam Candi Sumberawan menunjukkan keterkaitan manusia dengan air. Nilai budaya ini sebaiknya tersampaikan kepada para generasi penerus, sekaligus mata rantai yang menyambungkan ruangruang dan penggal-penggal sejarah.

\subsection{Analisis}

Analisis kesesuaian lahan bertujuan untuk mengetahui zona yang sesuai untuk dikembangkan sebagai kawasan wisata sejarah Candi Sumberawan yang berkelanjutan. Kawasan Candi Sumberawan 
memiliki tutupan lahan yang cukup beragam. Tutupan lahan diartikan kondisi kenampakan biofisik permukaan bumi yang diamati (Sampurno dan Thoriq, 2016). Berdasarkan survei lapang yang dilakukan menggunakan alat GPS bahwa tutupan lahan didominasi pertanian lahan kering semusim (Tabel 2) dan (Gambar 3).

Tabel 2. Luas Tutupan Lahan Kawasa Candi Sumberawan

\begin{tabular}{|c|c|c|c|}
\hline \multirow{2}{*}{ No } & \multirow[t]{2}{*}{ Jenis tutupan lahan } & \multicolumn{2}{|c|}{ Luas } \\
\hline & & $\mathrm{Ha}$ & $\%$ \\
\hline & Hutan Campur & 4,83 & $30,57 \%$ \\
\hline & Hutan Pinus & 0,81 & $5,13 \%$ \\
\hline & Persawahan & 1,66 & $10,50 \%$ \\
\hline & Pertanian Lahan Kering Semusim & 6,64 & $42,02 \%$ \\
\hline & Sungai & 0.77 & $4,87 \%$ \\
\hline & Air Bendungan & 0.25 & $1,58 \%$ \\
\hline & Kawasan Situs Candi & 0.12 & $0,76 \%$ \\
\hline & Pemukiman & 0.52 & $3,30 \%$ \\
\hline & Semak & 0.20 & $1,27 \%$ \\
\hline & Total & 15,80 & $100 \%$ \\
\hline
\end{tabular}

Sumber: Survei (2019)

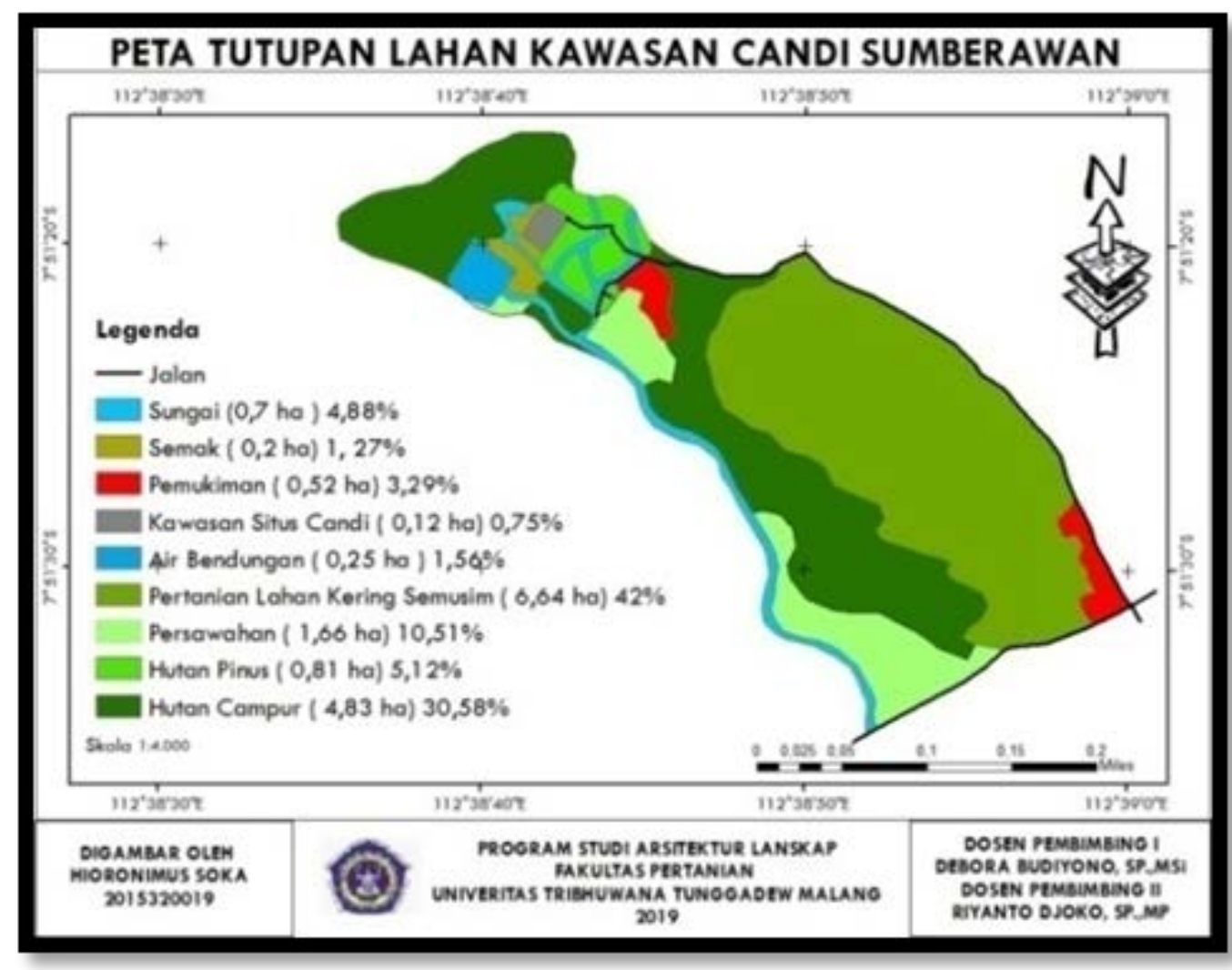

Gambar 3. Peta Tutupan Lahan Kawasan Candi Sumberawan

\subsubsection{Analisis Topografi}

Berdasarkan kelas kemiringan lereng, maka kondisi morfologi lahan yang datar akan mudah dikembangkan untuk zona aktifitas dan sebaliknya semakin tinggi kemiringan lereng maka semakin sulit untuk dikembangkan sebagai zona aktifitas. Penilaian topografi pada lokasi Kawasan Sumberawan dibagi menjadi tiga keriteria, yaitu curam (permukaan lereng $>65 \%$ ) dengan skoring 1 , miring (permukaan lereng 
15-65\%) dengan skoring 2, dan landai (permukaan lereng 0-15\%) dengan skoring 3 (Tabel 1). Kawasan Candi Sumberawan memiliki klasifikasi Sangat Sesuai dengan luas 10,2 ha (64,56\%), klasifikasi Sesuai dengan luas 4,83 (30,57\%), dan kawasan klasifikasi Kurang Sesuai dengan luas 0,77 ha $(4,87 \%)$ dari total keseluruhan kawasan dengan luas 15,80 ha (100\%). Berdasarkan analisis spasial menunjukkan bahwa kawasan Candi Sumberawan berpotensi dikembangkan aktivitas wisata. Peta topografi dapat dilihat pada Gambar 4.

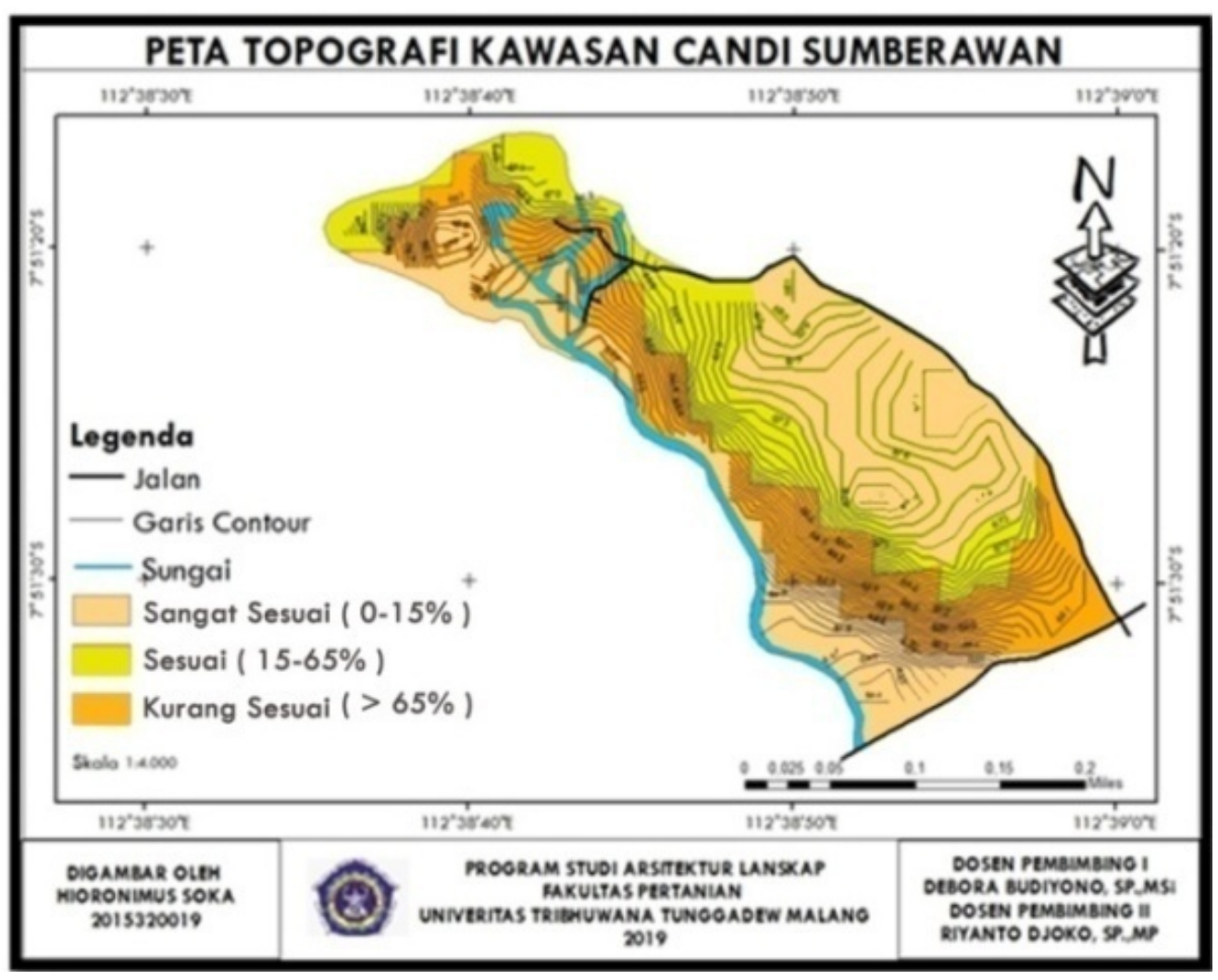

Gambar 4. Peta Topografi Kawasan Candi Sumberawan

\subsubsection{Analisis Karakteristik Tanah}

Kawasan Sumberawan berjenis tanah regosol dengan ciri butiran-kasar, belum menampakkan adanya lapisan horisontal, mempunyai variasi merah, kuning, coklat kemerahan, coklat, dan coklat kekuningan. Pebedaan warna tergantung pada material yang dikandungnya. Penilaian karakteristik tanah pada lokasi Kawasan Sumberawan dibagi menjadi tiga keriteria, yaitu berbatu banyak (>90\% volume tanah) dengan skoring 1, berbatu sedang (15-90\% volume tanah) dengan skoring 2, berbatu sedang (15-90\% volume tanah) dengan skoring 2, dan berbatu sedang (0-15\% volume tanah) dengan skoring 3 (Tabel 1 ). Berdasarkan analisis spasial menunjukkan bahwa kawasan Candi Sumberawan secara keseluruhan memiliki klasifikasi Sesuai dengan luas 15,80 ha (100\%) sehingga berpotensi dikembangkan berbagai aktivitas wisata dan pembangunan fasilitas wisata yang ramah lingkungan. Peta karakteristik tanah dapat dilihat pada Gambar 5. 


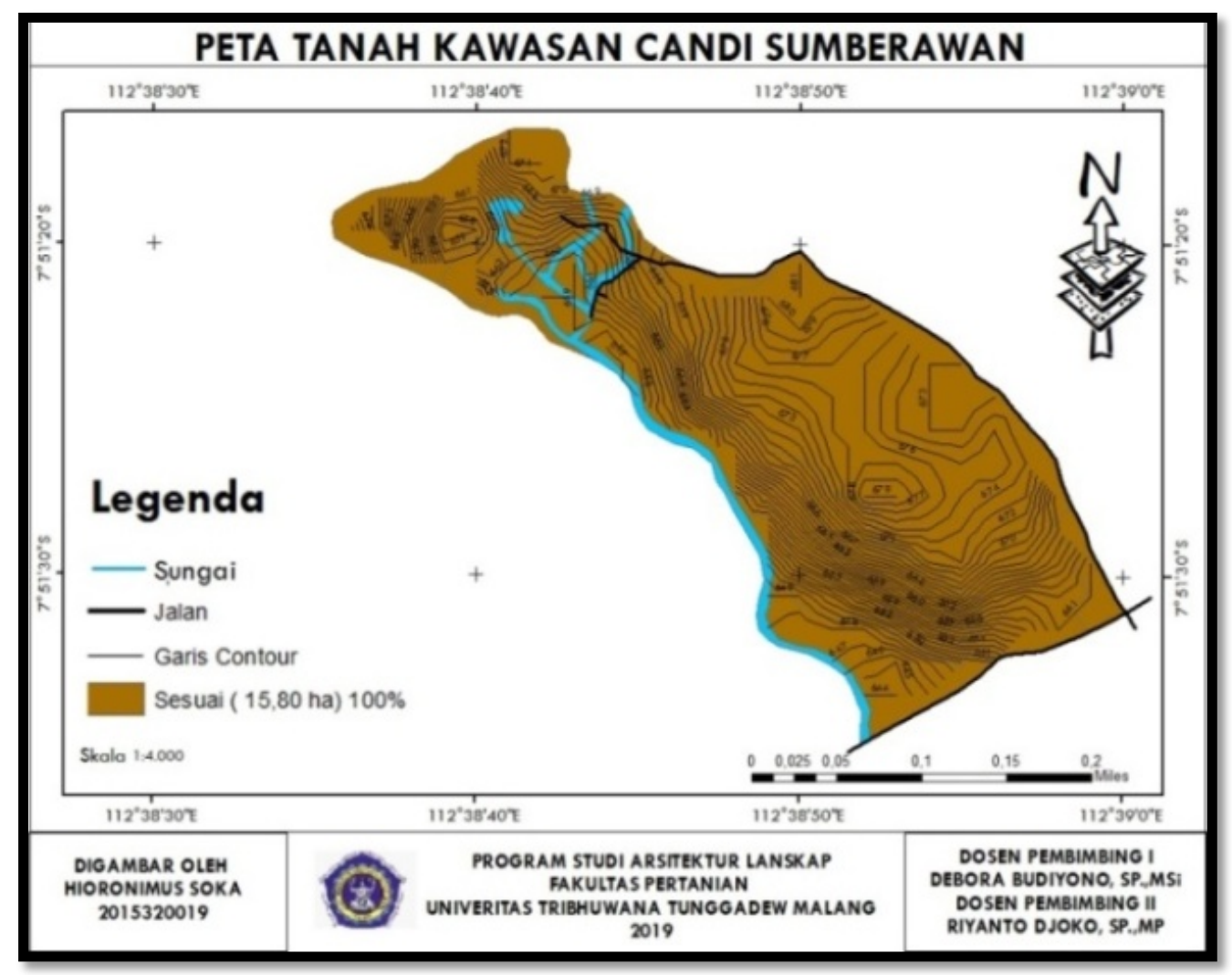

Gambar 5. Peta Karakteristik Tanah kawasan Candi Sumberawan

\subsubsection{Analisis Hidrologi}

Dusun Sumberawan saat ini mengalami penurunan kualitas dan kuantitas air seperti BOD yang semakin tinggi $311,33 \mathrm{mg} / \mathrm{L}$ dan penurunan debit air $1.750 \mathrm{~m}^{3}$ dengan indeks kualitas air berkisar antara 1,27-2,13, nilai terendah $1,27 \mathrm{~m}^{3}$, lokasi mata air Sumberawan per kapita pertahun (Rahmawati dan Retnaningdyah, 2014). Penilaian hidrologi pada lokasi Kawasan Sumberawan dibagi menjadi tiga keriteria, yaitu kotor (berwarna dan berbau) dengan skoring 1, Keruh (berwarna) dengan skoring 2, dan jernih (tidak berwarna) dengan skoring 3 (Tabel 1). Berdasarkan analisis spasial menunjukkan bahwa kawasan Candi Sumberawan Kawasan memiliki klasifikasi Sangat Sesuai dengan luas 0,25 ha (1,56\%), klasifikasi Sesuai dengan luas 0,7 ha $(4,88 \%)$, dan kawasan klasifikasi Kurang Sesuai dengan luas 14,85 ha $(93,56 \%)$ dari total keseluruhan kawasan 15,80 ha (100\%). Hal ini menunjukkan bahwa hidrologi di kawasan Candi Sumberawan cukup berpotensi dikembangkan sebagai wisata namun perlu pembatasan aktifitas yang dapat merusak kualitas ekosistem mata air. Peta hidrologi dapat dilihat pada Gambar 6. 


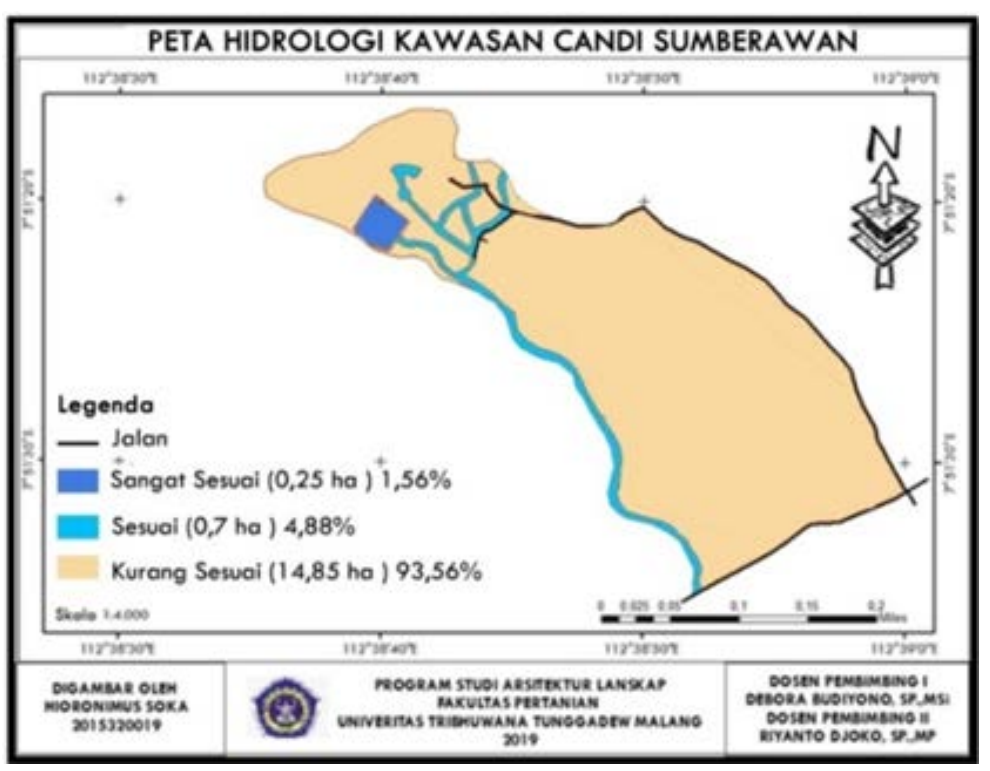

Gambar 6. Peta Hidrologi Kawasan Candi Sumberawan

\subsubsection{Analisis Kesesuaian Lahan Kawasan Candi Sumberawan}

Analisis kesesuaian lahan merupakan hasil overlay peta topografi, karakteristik tanah, dan hidrologi terhadap tutupan lahan. Penilaian kesesuaian lahan berdasarkan tutupan lahan dibagi menjadi tiga kriteria yaitu tidak alami (penutupan ekosistem < 40\%) dengan skor 3, semi alami (penutupan ekosistem 40-80\%) dengan skor 2, dan alami (penutupan ekosistem alami > 80\%) dengan skor 1. Berdasarkan hasil analisis kesesuaian lahan kawasan Candi Sumberawan menunjukkan klasifikasi zona Cukup Sesuai 12,96 Ha (82\%) dan zona Sangat Sesuai 2,84 Ha (18\%) (Tabel 3). Hal ini menunjukkan Kawasan Candi Sumberawan dapat dikembangkan sebagai kawasan wisata berbasis sejarah. Peta zona kesesuaian lahan Candi Sumberawan dapat dilihat pada Gambar 7.

Tabel 3. Penilaian Kesesuaian Lahan Kawasan Candi Sumberawan

\begin{tabular}{|c|c|c|c|c|c|c|c|}
\hline No & Jenis penggunaan & Topografi & Tanah & Hidrologi & Total & Klasifikasi & $\begin{array}{l}\text { Luas } \\
(\mathrm{Ha})\end{array}$ \\
\hline 1 & Hutan Campur & 2 & 3 & 1 & 6 & CS & 4,83 \\
\hline 2 & Hutan Pinus & 3 & 3 & 2 & 8 & SS & 0,81 \\
\hline 3 & Persawahan & 3 & 3 & 3 & 9 & SS & 1,66 \\
\hline 4 & $\begin{array}{l}\text { Pertanian Lahan Kering } \\
\text { Semusim }\end{array}$ & 2 & 2 & 2 & 6 & CS & 6,64 \\
\hline 5 & Sungai & 3 & 2 & 2 & 7 & CS & 0.77 \\
\hline 6 & Air Bendungan & 3 & 2 & 3 & 8 & SS & 0,25 \\
\hline 7 & Kawasan Situs Candi & 3 & 3 & 3 & 9 & SS & 0,12 \\
\hline 8 & Pemukiman & 2 & 2 & 2 & 6 & CS & 0,52 \\
\hline \multirow[t]{2}{*}{9} & Semak & 2 & 2 & 2 & 6 & CS & 0,20 \\
\hline & Total (Ha) & & & & & & 15,80 \\
\hline
\end{tabular}

Sumber: Survei (2019)

KS: kurang sesuai, CS: cukup sesuai, SS: sangat sesuai

N:nilai, K: klasifikasi, KS: kurang sesuai (<3), CS: cukup sesuai (4-6), SS: sangat sesuai (7-9) 


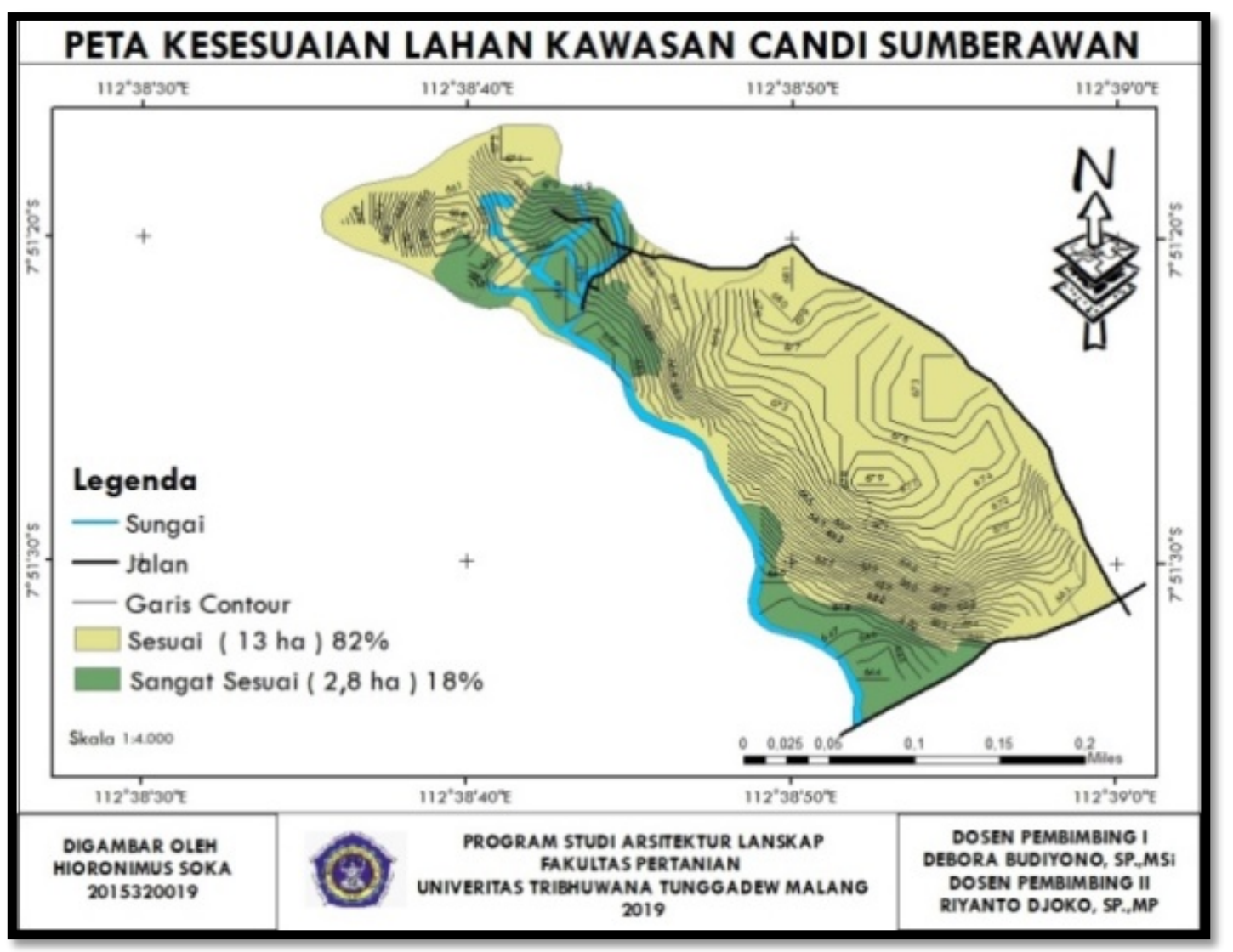

Gambar 7. Peta Zona Kesesuaian Lahan Kawasan Candi Sumberawan

\section{Simpulan}

Analisis kesesuaian lahan berdasarkan topografi, karakteristik tanah, dan hidrologi terhadap tutupan lahan menunjukkan bahwa terdapat dua zona yaitu Sangat Sesuai seluas 2,84 Ha (18\%) dan Cukup Sesuai dengan luas $12,96 \mathrm{Ha}(82 \%)$ dari dari total kawasan $15,80 \mathrm{Ha}$. Hal ini menunjukkan lanskap kawasan Candi Sumberawan dapat dikembangkan sebagai kawasan wisata sejarah di kecamatan Singosari, Kabupaten Malang, Jawa Timur. Namun pengembangan lanskap kawasan Candi Sumberawan harus disertai tindakan pelestarian dan pengelolaan yang berkelanjutan.

\section{Daftar Pustaka}

Badan Meteorologi, Klimatologi, dan Geofisika. (2018). Analisis curah hujan bulan september 2018. http://bmkg.go.id (diakses 21 September 2019, 16:18 WIB).

Budiyono, D. (2013). Perencanaan Lanskap Kawasan Wisata Pesisir Lalong Kota Luwuk, Sulawesi Tengah. Jurnal Lanskap Indonesia, 5 (2): 21-27.

Buwono, N. R., Muda G. O., dan Arsad, S. (2017). Pengelolaan Mata Air Sumberawan Berbasis Masyarakat di Desa Toyomarto Kecamatan Singosari Kabupaten Malang. Jurnal IImiah Perikanan dan Kelautan. 9 (1) 25-36.

Hardjowigono, S dan Widiatmaka. (2007). Evaluasi Kesesuaian Lahan dan Perencanaan Tataguna Lahan. Universitas Gajah Mada Press, Yokyakarta.

Lopes, N. (2016). Kajian Kearifan Lokal Masyarakat dalam Melestarikan Kawasan Candi Sumberawan, Kecamatan Singosari, Kabupaten Malang. Skripsi. Universitas Tribhuwana Tunggadewi Malang.

Maryanto, D. A. (2007). Seri Fakta dan Rahasia di Balik Candi: Mengenal Candi. Citra Aji Parama, Yogyakarta:

Piduwatu, B. (2015). Strategi Pengelolaan Lanskap Candi Sumberawan Kecamatan Singosari, Kabupaten Malang. Skripsi. Universitas Tribhuwana Tunggadewi Malang. 
Rahmawati, E. T dan Retnaningdyah, C. (2014). Karakteristik Vegetasi Riparian dan Interaksinya dengn Kualitas Air Mata Air Sumberawan serta Salurannya di Kecamatan Singosari Malang. Jurnal Biotropika, 2 (3): 136-141.

Ramli, S dan Wikantiyoso, R. (2018). Makna Ruang sebagai Aspek Pelestarian Situs Sumberawan. Jurnal Local Wisdom, 10 (1): 31-42.

Sampurno, R. M dan Thoriq, A. (2016). Klasifikasi Tutupan Lahan Menggunakan Citra Landsat 8 Operational Land Imager (oli) di Kabupaten Sumedang. Jurnal Teknotan, 10 (2): 61-70.

Sitawati, Budiyono, D., dan Nurlaelih, E. E. (2015). Study on The Local Wisdom of Sumberawan Society on Arjuno Mountain in Landscape Management. Proceedings of The Future Mountain and Volcanoscape: Creativity to Prosperity, Lombok: 7-9 September 2015. Pp. 246-254.

Titisari. (2017). Intangible Cultural Heritage Candi Sumberawan dalam Perspekstif Kosmologi. Prosiding Seminar Nasional "Heritage: Tangible and Intangible Aspects". Cirebon: Mei 2017. Hal. 17-22.

Tirtasari, E. Y., Antariksa, Dwi L. W, dan Surjono. (2017). Intangible Cultural Heritage Candi Sumberawan dalam Perspekstif Kosmologi. Prosiding Seminar Nasional Heritage IPLBI, Cirebon: Mei 2017. Hal. 16.

Wurianto, A. B. (2009). Aspek Budaya pada Upaya Konservasi Air dalam Situs Kepurbakalaan dan Mitologi Masyarakat Malang. Jurnal Humanity, 4 (2): 80-88. 